\title{
Adaptability of brazilian beans cultivars to industrial canning
}

\section{Vanderleia Schoeninger ${ }^{*}$ (i) Silvia Renata Machado Coelho ${ }^{2}$ (i) Priscila Zaczuk Bassinello $^{3}$ (i) Naimara Vieira do $\operatorname{Prado}^{4}$ (i) Tábata Zingano Bischoff Soares ${ }^{5}$ (i) Valdiney Cambuy Siqueira ${ }^{1}$ (i)}

${ }^{1}$ Faculdade de Ciências Agrárias, Universidade Federal da Grande Dourados (UFGD), 79804-970, Dourados MS, Brasil. E-mail: vschoeninger@ufgd.edu.br. ${ }^{*}$ Corresponding author.

${ }^{2}$ Programa de Pós-graduação em Engenharia Agrícola, Universidade Estadual do Oeste do Paraná (Unioeste), Cascavel, PR, Brasil.

${ }^{3}$ Empresa Brasileira de Pesquisa Agropecuária (Embrapa), Embrapa Arroz e Feijão, Goiânia, GO, Brasil.

${ }^{4}$ Universidade Tecnológica Federal do Paraná, Francisco Beltrão, PR, Brasil.

${ }^{5}$ Assist Consultoria e Experimentação Agronômica, Campo Verde, MT, Brasil.

ABSTRACT: A current alternative for meeting the modern consumer's beans food demands is the industrial processing. This study evaluated the adaptability of eight Brazilian beans cultivars to industrial canning from commercial class cultivars of Carioca and of Black beans. The grains were processed in an industry sector using metallic cans with a capacity of $420 \mathrm{~g}$, where the samples were conditioned without previous hydration. The cooking and sterilization process took place in a rotating autoclave. Quality parameters were evaluated in the canned beans. As a result, it was verified that, for the Carioca class, the Estilo cultivar differs from the rest of the genetic materials in terms of its low drained weight, which contributes to the increase in the total solids in the sauce, which have low hardness values. Estilo cultivar is not suitable for the type of processing used in this experiment. For the Black class, similar quality characteristics were observed between Esplendor and Uirapuru and between Esteio and Campeiro cultivars, where the latter stands out due to its lower damaged bean indices after processing. Finally, with the information present in this paper we intend to contribute to future researches on this subject and thereby increase the consumption and exportation of beans as processed product.

Key words: Phaseolus vulgaris L., canned beans, hydration coefficient, tegument color.

Adaptabilidade de cultivares brasileiras de feijão ao processamento industrial tipo enlatado

RESUMO: Atualmente uma alternativa alimentar que atende às demandas do consumidor moderno é o processamento industrial do feijão. Foi avaliada a adaptabilidade de oito cultivares de feijão ao processamento industrial. Os grãos foram processados em uma indústria do setor, utilizando-se embalagens metálicas com capacidade de $420 \mathrm{~g}$, nas quais as amostras foram acondicionadas sem o emprego de hidratação prévia. O processo de cozimento e esterilização foi realizado em autoclave rotativa. No feijão enlatado foram então avaliados os parâmetros de qualidade. Como resultado, verificou-se que, na classe Carioca, o cultivar BRS Estilo diferencia-se dos demais, devido ao baixo peso drenado que contribuiu para o aumento de sólidos totais no caldo, com baixos valores de dureza, não se adaptando ao tipo de processo utilizado neste experimento. Na classe Preto, observaram-se características de qualidade semelhantes entre BRS Esplendor e IPR Uirapuru, e entre BRS Esteio e BRS Campeiro, destacando-se esta última por apresentar menores índices de grãos danificados após o processamento. Por fim, com as informações presentes neste trabalho pretende-se contribuir com pesquisas futuras sobre o tema e dessa forma incrementar o consumo do feijão e sua exportação na forma de produto processado.

Palavras chave: Phaseolus vulgaris L., feijão enlatado, coeficiente de hidratação, cor do tegumento.

\section{INTRODUCTION}

Beans stand out in the world stage as a Fabaceae rich in proteins and of high nutritional value and are among the most cultivated species worldwide (OSORIO-DÍAZ et al., 2002; SIQUEIRA et al., 2014). Beans are considered a basic food and the main vegetable source of protein. In addition, the common bean Phaseolus vulgaris L. is the world's second most produced legume, after the soybean, followed by the cowpea and the chickpea (SIDDIQ \& UEBERSAX, 2013; SLUPSKI, 2010).

The industrial processing of beans through canning is a common practice in many countries where 
there is a consolidated habit for the consumption of that type of product (WHITE \& HOWARD, 2013). Industrially processed beans present an adequate nutritional profile and are good sources of protein, dietary fiber and minerals; have a low-fat content; and contain bioactive compounds with health benefits (PEDROSA et al., 2015), such as glycemic control and the reduced risk for some types of cancer. In Brazil, beans are traditionally consumed dry for home cooking, although in recent years, an increase in the options for processed beans in the market has been observed. Consumers seek certain characteristics in processed beans, such as texture, bean integrity, color and appearance, digestibility, convenience and energy economy at the time of preparation (MERWE, OSTHOFF \& BLACKRIUS, 2006a).

However, some alterations can be verified in the quality of beans subjected to industrial processing for canning due to various factors, such as differences in the cultivars, cultivation environment, cultivar $\mathrm{x}$ environment interaction (considered significant for the quality of processed beans) and the conditions and time of raw material storage ( SCHOENINGER et al., 2017; CICHY et al., 2014; MENDOZA et al., 2014; WRIGHT \& KELLY, 2011; POSA-MACALINCAG et al., 2002; LANGE, 1999; WALTERS et al., 1997; HOSFIELD et al., 1984). The raw material selection is also often viewed as problematic since many companies perform their selection using simple visual analysis by a trained group that evaluates a limited number of quality parameters, such as hydration capacity, drained weight (DW), grain size and damage index. Other matters related to texture and coloration are ultimately not verified, and the product often does not achieve market acceptance (MERWE, OSTHOFF \& BLACKRIUS, 2006a).

Research in Brazil regarding the industrial processing for canning of the species Phaseolus vulgaris L. is currently scarce because local consumers are not in the habit of using this type of product (FERNANDES, 2012; WANDER et al., 2006). Nonetheless, some studies can be found in this country related to the processing of the species Vigna unguiculata (L.) Walp, which is highly accepted by consumers in many Brazilian regions (BENEVIDES et al., 2013; LIMA et al., 2003). The industrialization of foods is a way to guarantee a rational and regular supply for consumers (GAVA, 2008). Therefore, industrial processing is an interesting alternative for the bean market. Providing information and solutions for the bean transformation industry and offering indications for improvement programs is currently becoming a necessity. A successful bean variety does not entail only high yields in the fields but must present value throughout the production chain (KHANAL et al., 2014). The ideal genotype must display superior agronomical performance and should sustain an acceptable quality level for canning, regardless of the cultivation locale. Based on the above introduction, the goal of this study is to evaluate quality parameters in eight Brazilian beans cultivars subjected to industrial processing for canning.

\section{MATERIALS AND METHODS}

Common beans (Phaseolus vulgaris L.) recently harvested from different cultivars of the Carioca and Black commercial classes were used in this study. These beans were produced in the experimental area of Embrapa Arroz e Feijão, in Santo Antônio de Goiás - GO, Brazil. The Carioca class cultivars evaluated were BRS Pérola, BRS Estilo, BRS Ametista and BRS Notável, whereas the Black class cultivars were IPR Uirapuru, BRS Campeiro, BRS Esteio and BRS Esplendor. According to some processing plants in the country, the BRS Pérola and IPR Uirapuru cultivars are considered the best adapted to industrial processing for canning in the country.

The industrial processing took place in the facilities of the company Conservas Oderich, in the municipality of São Sebastião do Caí - RS - Brazil. In the facilities, the beans were washed with water and manually drained. Immediately afterward, between 126 and $130 \mathrm{~g}$ of each product was placed in a tin can with a capacity of $420 \mathrm{~g} \mathrm{(73} \mathrm{mm}$ in diameter and $110 \mathrm{~mm}$ in height). Then, the tin cans were filled with water at a temperature of $75{ }^{\circ} \mathrm{C}$, leaving a headspace of 3 to $5 \mathrm{~mm}$. The cans were automatically closed and sealed; cooking and sterilization of the product was then performed in a rotating autoclave $\left(\right.$ Ferlo $\left.^{\circledR}\right)$ with a frequency of $11 \mathrm{~Hz}$, using pressurized water at a temperature of $120{ }^{\circ} \mathrm{C}$ and a pressure of $1.2 \mathrm{~kg}$ for heating. The total time for this stage was $120 \mathrm{~min}$, in which $19 \mathrm{~min}$ was dedicated to heating, $35 \mathrm{~min}$ was dedicated to cooking, and 66 min was dedicated to gradual cooling of the product inside the machine.

After processing, the samples were transported to the laboratory and kept at room conditions for a period of two weeks to guarantee the stabilization and equilibration of the sauce. Next, the samples were characterized according to the quality parameters of canned beans.

First, the raw weight (RW), liquid weight and DWs were measured (in grams), the latter being 
verified according to with MERWE, OSTHOFF \& BLACKRIUS (2006a).The headspace in the can was measured $(\mathrm{mm})$ with the aid of a digital caliper. A $100 \mathrm{~g}$ sample of the processed product (beans and sauce) was subjected to visual evaluation to identify its appearance and any damage. The weight of the broken, damaged and/or cracked beans was measured for a damage index calculation (\%) for the process. The final product color parameters were obtained by placing a $50 \mathrm{~g}$ product sample (beans and sauce) in a Petri dish, followed by a colorimeter reading. For this was used a colorimeter (Konica Minolta ${ }^{\circledR}$ CR410) with a $50-\mathrm{mm}$ aperture, whose system considers the coordinates $\mathrm{L}^{*}, \mathrm{a}^{*}$ and $\mathrm{b}^{*}$ (CIELAB), responsible for luminosity and levels of red-green and blue-yellow, respectively. The device was previously calibrated on a ceramic plate according to the standards established by the manufacturer $(\mathrm{Y}=85.8 ; \mathrm{x}=0.3195$; $\mathrm{y}=$ $0.3369)$, using the D65 illuminant, which represented average daylight. The readings were taken in triplicate for each of the studied cultivars. The hue angle parameters $\left(\mathrm{H}^{*}\right)$ and chroma $\left(\mathrm{C}^{*}\right)$ of the beans were determined using equations 1 and 2 , respectively:

$$
\begin{gathered}
H^{*}=\tan ^{-1}\left(\frac{b^{*}}{a^{*}}\right) \\
C^{*}=\sqrt{\left(a^{*}\right)^{2}+\left(b^{*}\right)^{2}}
\end{gathered}
$$

where

$\mathrm{H}^{*}=$ hue angle or chromatic tonality

$\mathrm{a}^{*}=$ green-red component

$\mathrm{b}^{*}=$ blue-yellow component

$\mathrm{C}^{*}=$ chroma

The soluble solids concentration (SS) (\%) was determined for the processed bean sauce by direct reading (in ${ }^{\circ}$ Brix) with an Abbe-type bench refractometer. The total solids concentration (TS) (\%) of the sauce was determined using a $10-\mathrm{mL}$ sample of drained sauce, dried in an oven at a temperature of $80{ }^{\circ} \mathrm{C}$ for $24 \mathrm{~h}$ (MATELLA, MISHRA \& DOLAN, 2013). The $\mathrm{pH}$ parameters were also evaluated by direct reading; acidity (\%) was measured by titration with $0.01 \mathrm{M} \mathrm{NaOH}$ (AOAC, 2000). The processed product texture was determined in a texture meter (TA.XT Plus, Stable Micro Systems ${ }^{\circledR}$ ) using 25 beans, which were individually analyzed, dried with paper towels, placed on the meter platform and compressed to $90 \%$ of their initial height using a $50 \mathrm{~kg}$ load cell. The maximum compression force $\left(\mathrm{N}\right.$. grain $\left.{ }^{-1}\right)$ was used as an indicator of the hardness of the canned beans (GHASEMLOU et al., 2013).

The experiment was repeated three times, and the data were verified in terms of normality (Shapiro-Wilk test) and equality of variances (Bartlett test) at a level of $5 \%$ of significance. The variance analysis F test was used (ANOVA) to compare the cultivars of both classes, Carioca and Black, with a Tukey average comparison test at a 5\% significance level. A Box-Cox transformation was used for the data that did not meet the normality and variance equality criteria; however, when that transformation was inefficient, the Kruskal-Wallis test was used to compare the cultivars.

\section{RESULTS AND DISCUSSION}

Table 1 presents the average values of the quality parameters for canned beans, evaluated for Brazilian cultivars of the commercial classes Carioca and Black. For the RW and net weight (NW), significant differences were found between the averages of Carioca class cultivars, with a RW variation between 473.90 and $490.65 \mathrm{~g}$ and an NW variation between 412.12 and $429.56 \mathrm{~g}$ for the cultivars BRS Estilo and BRS Notável, respectively. In the Black class, the RW was highest for BRS Esteio (497.40), followed by BRS Campeiro (497.34), with statistically equal values between them, and different from the averages of the other cultivars. The NW varied between 417.01 and 437.58; NW values were statistically equal for BRS Campeiro and BRS Esteio and for IPR Uirapuru and BRS Esplendor $(\mathrm{p}<0.05)$. The drained weight (DW) varied between $304.42 \mathrm{~g}$ and $363.90 \mathrm{~g}$ in the Carioca class for BRS Estilo and BRS Ametista, with statistically equal averages between BRS Ametista, BRS Pérola and BRS Notável, with the latter value being equal to that for BRS Estilo, at a significance level of $5 \%$. The percentile drained weight (PDW), i.e., the ratio between DW and NW of the canned beans, varied between 73.89 and $88.29 \%$, with statistically equal averages for the cultivars BRS Ametista (88.25\%) and BRS Pérola (85.29\%). For the Black class, the BRS Esplendor cultivar had the highest DW (357.20), which also implied a greater value for the PDW $(84.62 \%)$. The other cultivars presented statistically equal DW averages. BALASUBRAMANIAN et al., (2000) found that the PDW was lowest for black beans $(61.90 \%)$, followed by Pinto beans $(63.80 \%)$, and was highest for Navy beans $(67.70 \%)$. MERWE, OSTHOFF \& BLACKRIUS (2006a) and MERWE, OSTHOFF \& BLACKRIUS (2006b) measured PDW variations from 68.83 to $78.80 \%$ when evaluating four bean cultivars originating from nine production locales, lower values than those obtained in this work. Indeed, according to those authors, the minimum DW percentage for canned beans must be $60 \%$; thus, the cultivars of both classes displayed acceptable values. 
Table 1 - Average physical quality values for canned beans: RW: raw weight (g); NW: net weight (g); DW: drained weight (g); PDW: percentile drained weight $(\%)$; H: headspace $(\mathrm{mm})$, color parameters $\mathrm{L}^{*}, \mathrm{a}^{*}, \mathrm{~b}^{*}, \mathrm{C}$ and $\mathrm{H}$; damage index $(\%)$; texture $\left(\mathrm{N} . g r a i n{ }^{-1}\right)$; SS: soluble solids ( ${ }^{\circ}$ Brix); TS: total solids (\%); $\mathrm{pH}$ and acidity, for cultivars of the commercial classes Carioca (BRS Ametista, BRS Notável, BRS Pérola and BRS Estilo) and Black (BRS Campeiro, BRS Esteio, BRS Esplendor and IPR Uirapuru.

\begin{tabular}{|c|c|c|c|c|c|c|}
\hline \multirow[t]{2}{*}{ Parameters } & \multicolumn{4}{|c|}{ 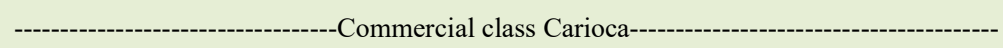 } & \multirow[t]{2}{*}{$\mathrm{CV}(\%)$} & \multirow[t]{2}{*}{ p-valor } \\
\hline & BRS Estilo & BRS Notável & BRS Pérola & BRS Ametista & & \\
\hline RW (g) & $473.90 \pm 7.41^{b}$ & $490.65 \pm 2.56^{\mathrm{a}}$ & $485.98 \pm 4.53^{\mathrm{ab}}$ & $476.38 \pm 2.99^{b}$ & 1.71 & 0.0079 \\
\hline NW $(g)$ & $412.12 \pm 10.48^{\mathrm{b}}$ & $429.56 \pm 4.03^{\mathrm{a}}$ & $421.27 \pm 3.93^{\mathrm{ab}}$ & $412.41 \pm 5.09^{\mathrm{b}}$ & 2.23 & 0.0313 \\
\hline DW (g) & $304.42 \pm 8.70^{\mathrm{b}}$ & $334.05 \pm 18.01^{\mathrm{ab}}$ & $359.28 \pm 11.80^{\mathrm{a}}$ & $363.90 \pm 9.85^{\mathrm{a}}$ & 7.92 & 0.015 \\
\hline PDW (\%) & $73.89 \pm 2.47^{\mathrm{c}}$ & $77.79 \pm 4.85^{\mathrm{bc}}$ & $85.29 \pm 3.14^{\mathrm{a}}$ & $88.25 \pm 2.93^{\mathrm{a}}$ & 8.22 & 0.0034 \\
\hline $\mathrm{H}(\mathrm{mm})$ & $9.44 \pm 2.13^{\mathrm{a}}$ & $3.33 \pm 0.96^{\mathrm{b}}$ & $4.98 \pm 1.17^{b}$ & $4.18 \pm 1.35^{b}$ & 48.08 & 0.006 \\
\hline $\mathrm{L}^{*}$ & $47.76 \pm 0.13^{\mathrm{a}}$ & $45.98 \pm 0.39^{\mathrm{a}}$ & $46.08 \pm 0.74^{\mathrm{a}}$ & $46.23 \pm 1.11^{\mathrm{a}}$ & 2.07 & 0.096 \\
\hline$a^{*}$ & $8.21 \pm 0.25^{\mathrm{b}}$ & $9.35 \pm 0.11^{\mathrm{a}}$ & $8.84 \pm 0.39^{\mathrm{ab}}$ & $8.89 \pm 0.22^{\mathrm{a}}$ & 5.42 & 0.004 \\
\hline$b^{*}$ & $9.65 \pm 0.70^{\mathrm{a}}$ & $10.33 \pm 0.24^{\mathrm{a}}$ & $10.68 \pm 0.46^{\mathrm{a}}$ & $10.38 \pm 0.52^{\mathrm{a}}$ & 5.73 & 0.1638 \\
\hline $\mathrm{C}$ & $12.67 \pm 0.68^{\mathrm{a}}$ & $13.94 \pm 0.25^{\mathrm{a}}$ & $13.87 \pm 0.59^{\mathrm{a}}$ & $13.69 \pm 0.46^{\mathrm{a}}$ & 5.16 & 0.059 \\
\hline $\mathrm{H}$ & $49.57 \pm 1.21^{\mathrm{a}}$ & $47.85 \pm 0.35^{\mathrm{a}}$ & $50.41 \pm 0.31^{\mathrm{a}}$ & $49.33 \pm 1.19^{\mathrm{a}}$ & 2.48 & $0.1031^{* *}$ \\
\hline Damage index $(\%)$ & $97.74 \pm 1.64^{\mathrm{a}}$ & $96.46 \pm 1.22^{\mathrm{a}}$ & $95.60 \pm 3.79^{\mathrm{a}}$ & $92.78 \pm 3.13^{\mathrm{a}}$ & 3.09 & 0.2137 \\
\hline Text $\left(\right.$ N.grain $\left.{ }^{-1}\right)$ & $0.60 \pm 0.22^{\mathrm{a}}$ & $0.75 \pm 0.20^{\mathrm{a}}$ & $0.66 \pm 0.24^{\mathrm{a}}$ & $0.70 \pm 0.15^{\mathrm{a}}$ & 31.23 & 0.095 \\
\hline $\mathrm{SS}\left({ }^{\circ}\right.$ Brix $)$ & $9.60 \pm 0.53^{\mathrm{a}}$ & $10.17 \pm 0.15^{\mathrm{a}}$ & $11.83 \pm 0.29^{c}$ & $10.83 \pm 0.29^{b}$ & 8.63 & 0.000 \\
\hline TS (\%) & $16.94 \pm 3.88^{\mathrm{a}}$ & $11.90 \pm 0.24^{b}$ & $12.45 \pm 0.09^{\mathrm{ab}}$ & $13.23 \pm 0.45^{\mathrm{ab}}$ & 15.18 & $0.015^{* *}$ \\
\hline $\mathrm{pH}$ & $6.33 \pm 0.08$ & $6.20 \pm 0.02$ & $6.34 \pm 0.03$ & $6.40 \pm 0.16$ & 1.72 & 0.1086 \\
\hline Acidity (\%) & $0.31 \pm 0.04^{\mathrm{a}}$ & $0.26 \pm 0.01^{\mathrm{ab}}$ & $0.20 \pm 0.01^{\mathrm{b}}$ & $0.26 \pm 0.03^{\mathrm{ab}}$ & 18.82 & 0.0067 \\
\hline \multirow[t]{2}{*}{ Parameters } & \multicolumn{4}{|c|}{--------------------------------------'Commercial class Black----------------------------------------- } & $\mathrm{CV}(\%)$ & $\mathrm{p}$-valor \\
\hline & BRS Esplendor & BRS Campeiro & BRS Esteio & IPR Uirapuru & & \\
\hline RW (g) & $486.13 \pm 4.90^{\mathrm{ab}}$ & $497.34 \pm 5.44^{\mathrm{a}}$ & $497.40 \pm 5.65^{\mathrm{a}}$ & $481.21 \pm 5.99^{b}$ & 1.01 & 0.015 \\
\hline NW $(g)$ & $422.10 \pm 0.96^{\mathrm{b}}$ & $437.58 \pm 5.02^{\mathrm{a}}$ & $437.17 \pm 5.74^{\mathrm{a}}$ & $417.01 \pm 7.33^{\mathrm{b}}$ & 2.54 & 0.027 \\
\hline DW $(g)$ & $357.2 \pm 10.28^{\mathrm{a}}$ & $332.22 \pm 9.85^{\mathrm{b}}$ & $329.81 \pm 2.47^{\mathrm{b}}$ & $336.80 \pm 4.23^{\mathrm{b}}$ & 3.83 & 0.0079 \\
\hline PDW $(\%)$ & $84.62 \pm 2.26^{\mathrm{a}}$ & $75.92 \pm 1.63^{b}$ & $75.45 \pm 1.47^{b}$ & $80.77 \pm 0.40^{\mathrm{a}}$ & 5.25 & 0.000 \\
\hline $\mathrm{H}(\mathrm{mm})$ & $7.41 \pm 1.80^{\mathrm{a}}$ & $4.39 \pm 0.91^{\mathrm{b}}$ & $5.04 \pm 1.59^{\mathrm{ab}}$ & $7.20 \pm 1.44^{\mathrm{ab}}$ & 28.16 & 0.027 \\
\hline $\mathrm{L}^{*}$ & $36.67 \pm 0.35^{b}$ & $38.76 \pm 0.63^{\mathrm{a}}$ & $39.05 \pm 0.58^{\mathrm{a}}$ & $36.15 \pm 0.61^{b}$ & 3.71 & 0.044 \\
\hline$a^{*}$ & $3.48 \pm 0.13^{c}$ & $4.15 \pm 0.23^{b}$ & $4.33 \pm 0.16^{\mathrm{ab}}$ & $4.93 \pm 0.39^{\mathrm{a}}$ & 13.36 & 0.004 \\
\hline$b^{*}$ & $1.87 \pm 0.24^{\mathrm{b}}$ & $2.05 \pm 0.34^{\mathrm{b}}$ & $2.85 \pm 0.12^{\mathrm{a}}$ & $2.97 \pm 0.29^{\mathrm{a}}$ & 23.16 & 0.164 \\
\hline $\mathrm{C}$ & $3.95 \pm 0.22^{c}$ & $4.63 \pm 0.36^{\mathrm{bc}}$ & $5.18 \pm 0.20^{\mathrm{ab}}$ & $5.76 \pm 0.48^{\mathrm{a}}$ & 15.41 & 0.059 \\
\hline $\mathrm{H}$ & $28.13 \pm 2.32^{\mathrm{bc}}$ & $26.09 \pm 2.71^{\mathrm{c}}$ & $33.32 \pm 0.32^{\mathrm{a}}$ & $31.03 \pm 0.49^{\mathrm{ab}}$ & 11.56 & 0.041 \\
\hline Damage index (\%) & $81.71 \pm 3.42^{b}$ & $31.98 \pm 3.67^{c}$ & $85.25 \pm 2.39^{b}$ & $97.05 \pm 1.21^{\mathrm{a}}$ & 30.47 & 0.000 \\
\hline Text $\left(\right.$ N.grain $\left.{ }^{-1}\right)$ & $0.69 \pm 0.16^{\mathrm{c}}$ & $0.93 \pm 0.13^{\mathrm{b}}$ & $1.22 \pm 0.32^{\mathrm{a}}$ & $0.64 \pm 0.15^{\mathrm{c}}$ & 36 & 0.000 \\
\hline SS $\left({ }^{\circ}\right.$ Brix $)$ & $10.27 \pm 0.46^{\mathrm{a}}$ & $9.10 \pm 0.10^{\mathrm{b}}$ & $10.17 \pm 0.29^{\mathrm{a}}$ & $10.10 \pm 0.10^{\mathrm{a}}$ & 5.52 & 0.000 \\
\hline ST $(\%)$ & $13.27 \pm 0.80^{\mathrm{a}}$ & $10.74 \pm 0.24^{\mathrm{b}}$ & $11.66 \pm 0.18^{\mathrm{ab}}$ & $13.23 \pm 1.40^{\mathrm{a}}$ & 10.94 & 0.023 \\
\hline $\mathrm{pH}$ & $6.29 \pm 0.04$ & $6.22 \pm 0.00$ & $6.24 \pm 0.03$ & $6.28 \pm 0.06$ & 0.71 & 0.135 \\
\hline Acidity (\%) & $0.27 \pm 0.02$ & $0.27 \pm 0.03$ & $0.27 \pm 0.04$ & $0.29 \pm 0.05$ & 12.02 & 0.775 \\
\hline
\end{tabular}

Notes: Values are expressed as the mean values \pm standard deviations. $\mathrm{CV}=$ overall coefficient of variation. Averages on rows with different superimposed letters correspond to significantly different values, at a significance level of 5\%, according to the Tukey and Kruskal-Wallis tests $\left({ }^{* *}\right)$.

According to WHITE \& HOWARD (2013) and MATELLA, MISHRA \& DOLAN (2013), the parameters RW, NW and DW are important for maintaining the industrial quality standards for processed beans. The PDW is a quality parameter used for determining the precise hydration of the beans and the adequate proportion of sauce to be used in the process and is also associated with the industrial productivity (WALTERS et al., 1997).

According to KHANAL et al., (2014) low DW values may indicate excessive solid losses during processing and an increase in the agglutination 
degree of the product at the top of the packaging after processing and during storage. This effect is undesirable with low economic impact and could lead to the rejection of the cultivar by the processing industry since the high agglomeration degree of the product is viewed as a negative characteristic. The low PDW values displayed by BRS Estilo in the Carioca class and BRS Campeiro and BRS Esteio in the Black class indicate that this agglutination effect could occur in the product.

The average headspaces $(\mathrm{H})$ for the Carioca class cultivars were significantly different, with variations between 3.33 and $9.44 \mathrm{~mm}$ for BRS Notável and BRS Estilo, respectively. The BRS Notável, BRS Ametista and BRS Pérola cultivars displayed statistically equal averages $(\mathrm{p}<0.05)$, except for BRS Estilo, which had the highest value of H. Significant differences in $\mathrm{H}(\mathrm{p}<0.05)$ occurred in the Black class, with the lowest value of $4.39 \mathrm{~mm}$ for BRS Campeiro and the highest value of $7.41 \mathrm{~mm}$ for BRS Esplendor. For the color components of canned Carioca beans (Table $1)$, no significant differences in luminosity $\left(\mathrm{L}^{*}\right)$ were detected between the four cultivars after processing $(\mathrm{p}$ $>0.05)$. The $\mathrm{a}^{*}$ component displayed the highest value for BRS Notável (9.35) and the lowest value for BRS Estilo (8.21), with these two values being statistically significant. Therefore, the red color is predominant in the compositions of both evaluated cultivars, in greater measure for BRS Notável (MENDOZA, et al., 2006), with an increase of the $\mathrm{a}^{*}$ component value for the processed beans compared to the raw material. The other color parameters, including the $\mathrm{b}^{*}$ component (blue yellow), hue angle $\left(\mathrm{H}^{*}\right)$ (Kruskal-Wallis $\left.\mathrm{p}=0.1031\right)$ and chroma $\left(\mathrm{C}^{*}\right)$, did not present any significant differences between the four cultivars of the Carioca class. However, the $b^{*}$ color component presented by the beans decreased with processing, as observed in the comparison of the means of the processed beans and those of the raw product. According to GUZEL \& SAYAR (2013), various factors can alter the bean color during processing, the most common of which are degradation of the pigments, darkening reactions, ascorbic acid oxidation, acidity, and the presence of heavy metals. Therefore, the decrease in the values of the components $\mathrm{L}^{*}$ and $\mathrm{b}^{*}$ and the increase in $\mathrm{a}^{*}$ can be explained by the occurrence of pigment degradation during the industrial process employed.

In the Black class, the bean luminosity varied between 36.15 and 39.05 for IPR Uirapuru and BRS Esteio, respectively; these values were significantly different $(\mathrm{p}<0.05)$. The component $\mathrm{a}^{*}$ presented the lowest value for BRS Esplendor (3.48) and the highest for IPR Uirapuru (4.93).
The $b^{*}$ color component was statistically equal for IPR Uirapuru (2.97) and BRS Esteio (2.85), which presented the largest averages. BRS Campeiro and BRS Esplendor displayed lower averages for the blue-yellow light component, these numbers being were statistically equal. The chroma of the Black class beans (Table 1) presented values between 3.95 (BRS Esplendor) and 5.76 (IPR Uirapuru). Thus, the color perception intensity was largest for the IPR Uirapuru cultivar samples. For the hue angle $\left(\mathrm{H}^{*}\right)$, values between $26.08^{\circ}$ (BRS Campeiro) and $33.32^{\circ}$ (BRS Esteio) were found, with significant differences $(\mathrm{p}<0.05)$ between the cultivars. Canned bean hue is an important quality factor for consumers and can influence the market potential for the product (KHANAL et al., 2014). The damage index for Carioca class cultivars varied between 92.78\% for BRS Ametista and 97.74\% for BRS Estilo (Table 1), without any statistically significant differences $(p=0.2137)$. GUZEL \& SAYAR (2012) upon evaluating the processing of white Kidney beans and Cranberry beans (beige-colored bean with red stripes), also found high damage indices in the beans after processing. In the Black class, the BRS Campeiro cultivar stood out because it presented the lowest bean damage index after industrial processing (31.98\%). The IPR Uirapuru cultivar showed the highest average for the amount of product damaged, which was $97.05 \%$ and significantly different from the others; BRS Esteio (85.25\%) and BRS Esplendor $(81.71 \%)$ were statistically equal $(\mathrm{p}<0.05)$. Figure 1 shows the appearance of the beans from all eight cultivars of the Black and Carioca classes after the industrial canning process.

BRS Notável in the Carioca class and BRS Campeiro in the Black class presented the best appearance regarding grain integrity of the processed products. Damages were observed in these samples, although they appeared as only small tegument cracks and not as exploded grains, as in the case of the cultivars BRS Estilo and IPR Uirapuru. The high indices of structural defects in bean-based products such as canned beans are a problem for the industry since consumers prefer intact beans with a low incidence of structural defects. These tegument rupture defects generally occur in the hilum and micropyle of the bean structures (MERWE, OSTHOFF \& BLACKRIUS, 2006a; AZARPAZHOOH \& BOYE, 2013). Thus, damages in this region of the bean could be observed, especially in the samples of BRS Estilo, BRS Ametista and BRS Esteio cultivars. In the BRS Estilo cultivar, a high degree of rupture was observed due to grain explosion, with tegument detachment and dissolution of the bean contents into the sauce 
(Figure 1). For MERWE, OSTHOFF \& BLACKRIUS (2006a), it is important for the visual appearance of the processed, canned beans that husk detachment does not occur; the beans must be individually visible, with a shiny quality, and uniform in color and size. Indeed, according to those same authors, product agglomeration caused by starch leaching and dispersion of the cotyledon, followed by the increase in the sauce viscosity, are also undesirable characteristics of the final product.

It was also possible to measure the differences in color presented by the components $\mathrm{L}^{*}, \mathrm{a}^{*}, \mathrm{~b}^{*}, \mathrm{C}^{*}$ and $\mathrm{H}^{*}$ (Table 1 and Figure 1). These differences were observed to be small for the Carioca class cultivars. For the Black class beans, the BRS Esteio stood out from the rest by presenting greater luminosity and coloration, with a dark brown hue. The BRS Esplendor presented a sauce with a shiny aspect that was well distributed around the grains. The bean coloration is influenced by the anthocyanin content in the grain tegument; thus, the final product color may present variations due to the concentrations of these compounds in the raw material. When the color parameter values of the raw material and of the processed bean are compared, increases were observed in the values of the components $\mathrm{a}^{*}$ and $\mathrm{b}^{*}$ for the Black class beans. This finding indicates that the samples turned redder and yellower and became less green and blue, in the a* and $b^{*}$ scales, respectively, indicating the occurrence of anthocyanin leaching (WHITE \& HOWARD, 2013; CICHY, K. A. et al., 2014).

Black beans stood out from the other types by presenting high anthocyanin concentrations in the tegument, including delphinidin-3-glucoside, petudinine-3-glucoside and malvidn-3-glucoside, together with phenolic compounds with antioxidant capabilities; these components are related to health benefits (MENDOZA et al, 2014). According to CICHY et al. (2014), processors consider a Black class bean to be of good quality when it retains its coloration after canning, since many cultivars have a tendency toward changing color, appearing as a product of brown and grayish aspect resulting from the excessive leaching of anthocyanin during the industrial process. According to WRIGHT \& KELLY (2011), good color retention for the canned bean can also improve its nutritional value, in addition to contributing to the product appearance.

The texture, measured as the average hardness of the bean, quantifies the softness or firmness of the product after processing and is another determinant factor for the palatability of the canned product (KHANAL et al, 2014; MENDOZA et al., 2017). For Carioca class cultivars, the hardness varied between 0.60 and $0.75 \mathrm{~N}^{-g r a i n}{ }^{-1}$ (Table 1),

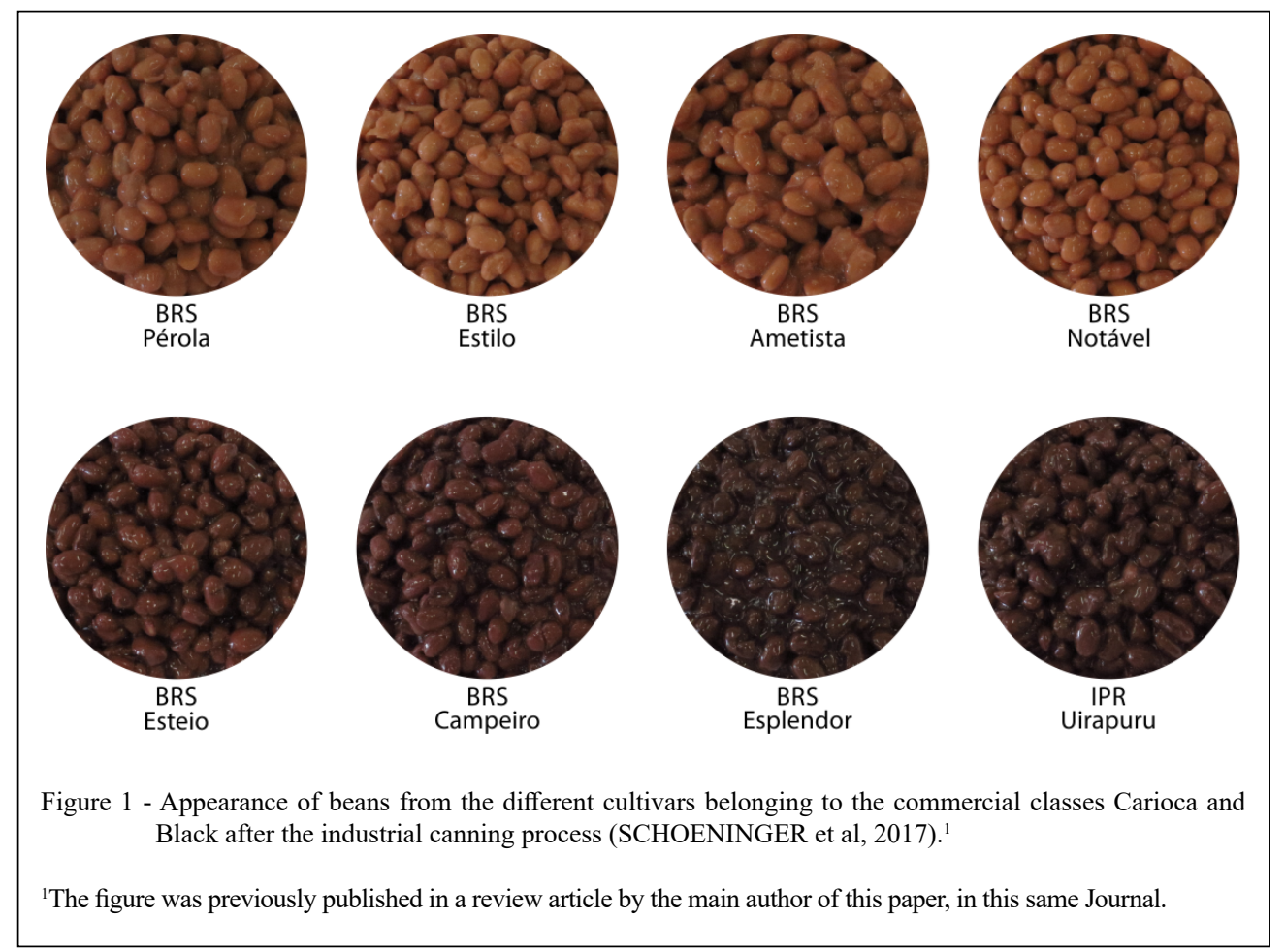

Ciência Rural, v.50, n.9, 2020. 
without a significant difference between the cultivars $(\mathrm{p}=0.085)$. However, in the Black class, there were differences, with the lowest value presented by IPR Uirapuru (0.64 N.grain $\left.{ }^{-1}\right)$ and the highest attributed to the BRS Esteio cultivar (1.22 N. grain $\left.{ }^{-1}\right)$. Thus, a greater softness was observed for processed beans of the Carioca commercial class. GUZEL \& SAYAR (2012) verified average hardness values of $0.80 \mathrm{~N}$. grain $^{-1}$ for white Kidney beans and $1.8 \mathrm{~N}$.grain ${ }^{-1}$ for Cranberry beans. BALASUBRAMANIAN et al., (2000) asserts that the hardness of Black class beans is higher than those of classes such as Navy and Pinto.

The SS degree in the sauce varied between 9.60 and $11.83^{\circ}$ Brix for BRS Estilo and BRS Pérola, respectively, with a statistically significant difference between the cultivars of the Carioca class. For Black class cultivars, BRS Campeiro presented the lowest mean value for SS $\left(9.10^{\circ}\right.$ Brix $)$, being different from those displayed by the other cultivars, which were statistically equal. GUZEL \& SAYAR (2012) found values that varied between 8.7 and $14.5^{\circ} \mathrm{Brix}$ for processed bean samples. Indeed, according to those same authors, these parameters can depend on the water content in the material, the type of grain and whether there is an occurrence of physical or chemical defects in the product, such as hard-tocook (HTC) beans. The TS index in the processed bean sauce was lowest for BRS Notável (11.90\%) and highest for BRS Estilo (16.94\%) (Table 1), with a significant difference between the studied samples (Kruskal-Wallis $\mathrm{p}=0$. 015). In the Black class, the lowest mean value was observed for BRS Campeiro $(10.74 \%)$, and the highest was observed for BRS Esplendor (13.27\%), with a difference between the cultivars $(\mathrm{p}<0.05)$.

There were no significant differences for the product $\mathrm{pH}$ parameter $(\mathrm{p}>0.05)$ in the samples of both evaluated bean classes, with values varying between 6.20 and 6.40 in the Carioca class and between 6.22 to 6.29 for Black class beans. According to MERWE, OSTHOFF \& BLACKRIUS (2006a) and MERWE; OSTHOFF \& PRETORIUS (2008), the $\mathrm{pH}$ is an important parameter for canned bean quality and can vary depending on the ingredients used in the sauce, which, if reduced, might interfere in reactions such as protein and starch hydrolysis. However, it is worthwhile mentioning that no additives were used in the present study; thus, the differences inherent to the $\mathrm{pH}$ were a function of the chemical composition of the beans. No statistically significant differences were found for the acidity for the Black class product, with variations between 0.27 and $0.29 \%$. In the Carioca class, the lowest average acidity was observed for BRS Pérola $(0.20 \%)$ and the highest for BRS Estilo (0.31\%).

\section{CONCLUSION}

For the Carioca class, it was verified that the BRS Estilo cultivar stands out due to its low DW, which increased the TS index in its sauce, in addition to low resistance with accentuated softness of the processed grain and higher damage index in the tegument. Therefore, this cultivar should not be indicated for the type of industrial processing used in this investigation. For beans of the Black commercial class, similar characteristics were observed for the BRS Esplendor and IPR Uirapuru and for the BRS Campeiro and BRS Esteio cultivars, especially due to the texture parameters RW and NW. BRS Campeiro stood out for presenting lower cracked and exploded grain indices, which also reduced the TS index in the product sauce. These cultivars will be able to be used by foreign industries in the processing of beans too.

We suggest that the cultivars evaluated in this experiment can be employed and evaluated for different processing protocols, where operations different than those of this investigation are used, such as hydration and bleaching of the grains procedures that are employed in some processing plants in Brazil. The obtained results contribute to orienting new research on the topic of canned beans in Brazil, where product chemical and sensorial attributes may be elucidated, in addition to providing information to the processing and importing industries and for genetic improvement programs.

\section{ACKNOWLEDGMENTS}

The authors thank the Brazilian Federal Agency for the Support and Evaluation of Graduate Education (Coordenação de Aperfeiçoamento de Pessoal de Nível Superior - CAPES) for its financial support through a scholarship (PDSE Processo: BEX 3175/14-6), the Conselho Nacional de Desenvolvimento Científico e Tecnológico (CNPq Universal 408785/2016-0), the Universidade Federal da Grande Dourados (PAP Program for researchers), Embrapa Arroz e Feijão for providing the generic material and the company Indústria Conservas Oderich for allowing us to perform the industrial processing of the beans.

\section{DECLARATION OF CONFLICT OF INTERESTS}

The authors declare no conflict of interest. The funding sponsors had no role in the design of the study; in the collection, analyses, or interpretation of data; in the writing of the manuscript, and in the decision to publish the results. 


\section{AUTHORS' CONTRIBUTIONS}

The authors contributed equally to the manuscript.

\section{REFERENCES}

AZARPAZHOOH, E.; BOYE, J. I. Composition of processed dry beans and pulses. In: Siddiq, M. Uebersax, M.A. Dry beans and pulses: production, processing and nutrition. Ames: Jonh Wiley \& Sons. p. 103-128. (2013).

Association of Official Analytical Chemists - AOAC. Official methods of analysis of the Association of Official Analytical Chemists. 17th ed. Gaithersburg: AOAC. (2000).

BALASUBRAMANIAN, P. et al. A modified laboratory canning protocol for quality evaluation of dry bean (Phaseolus vulgaris L). Journal of the Science of Food and Agriculture, 2000. v.80, n.6, p.732-738. Available from: <https://www.ncbi. nlm.nih.gov/pubmed/29345794>. Accessed: Jan. 20, 2020 doi: $\quad$ 10.1002/(SICI)1097-0010(20000501)80:6<732::AIDJSFA606>3.0.CO;2-X.

BENEVIDES, C. et al. Efeito do processamento sobre os teores de oxalato e tanino em maxixe (Cucumis anguria L.), jiló (Solanum gilo), feijão verde (Vigna unguiculata (L.) e feijão andu (Cajanus cajan (L.) Mill SP). Alimentos e Nutrição Araraquara, 2013. v.24, n.3, p.328. Available from: <http://serv-bib.fcfar.unesp.br/ seer/index.php/alimentos/article/viewArticle/321>. Accessed: Jan. 20,2020 .

CICHY, K. A. et al. QTL analysis of canning quality and color retention in black beans (Phaseolus vulgaris L.). Molecular Breeding, 2014. v.33, n.1, p.139-154. Available from: <https:// link.springer.com/article/10.1007/s11032-013-9940-y>. Accessed: Jan. 20, 2020. doi: 10.1007/s11032-013-9940-y.

FERNANDES, A. C. T et al. Técnicas de pré-preparo de feijões em unidades produtoras de refeições das regiões Sul e Sudeste do Brasil. Revista de Nutrição, 2012, v.25, n.2, p.259-269. Available from: <http://www.scielo.br/pdf/rn/v25n2/08.pdf > . Accessed: Jan. 20, 2020. doi: 10.1590/S1415-52732012000200008.

GAVA, A. J. et al. Tecnologia de alimentos: princípios e aplicações. Nobel, São Paulo. 644p. (2008).

GHASEMLOU, M. et al. Relating consumer preferences to textural attributes of cooked beans: Develpment of a industrial protocol and microstrutural observations. LWT - Food Science and Technology, 2013, v.50, p.88-98. Avaliable from: <https:// doi.org/10.1016/j.lwt.2012.06.018>. Accessed: Jan. 20, 2020. doi: 10.1016/j.lwt.2012.06.018.

GUZEL, D.; SAYAR, S. Effect of Cooking Methods on Selected Physicochemical and Nutritional Properties of Barlotto Bean, Chickpea, Faba Bean, and White Kidney Bean. Journal of Food Science and Technology, 2012, v.49, p.89-95. Available from: $<$ https://www.ncbi.nlm.nih.gov/pubmed/23572830>. Accessed: Jan. 20, 2020. doi: 10.1007/s13197-011-0260-0

HOSFIELD, G. L. et al. A factor analysis of yield and sensory and physico-chemical data from tests used to measure culinary quality in dry edible beans. Canadian Journal of Plant Science, 1984, v.64, p.285-293. Avaliable from: <https://doi.org/10.4141/cjps84042>. Accessed: Jan. 20, 2020. doi: 10.4141/cjps84-042.
KHANAL, R. et al. Genotypic association of parameters commonly used to predict canning quality of dry bean. Crop Science, 2014. v.54, n.6, p.2564-2573. Available from: <https://acsess. onlinelibrary.wiley.com/doi/full/10.2135/cropsci2014.02.0113>. Accessed: Jan. 20, 2020. doi: 10.2135/cropsci2014.02.0113.

LANGE, A. F. DE; LABUSCHAGNE, M. T. Genotype $\times$ environment interaction and principal factor analysis of seed characteristics related to canning quality of small white beans (Phaseolus vulgaris L.) in South Africa. South African Journal of Plant and Soil, 1999. v.16, n.4, p.192-196. Available from: $<$ https://www.tandfonline.com/doi/abs/10.10 80/02571862.1999.10635010>. Accessed: Jan. 20, 2020. doi: 10.1080/02571862.1999.10635010.

MATELLA, N. J.; MISHRA, D. K.; DOLAn, K. D. Hydration, blanching and thermal processing of dry beans. In: Siddiq, M.; Uebersax, M.A. Dry beans and pulses: production, processing and nutrition. Ames: Jonh Wiley \& Sons, p.129 - 154. (2013).

MENDOZA, F. A. et al. Evaluation of Canning Quality Traits in Black Beans (Phaseolus vulgaris L.) by Visible/Near-Infrared Spectroscopy. Food and Bioprocess Technology, 2014. v.7, n.9, p.2666-2678. Available from: <https://link.springer.com/ article/10.1007/s11947-014-1285-y>. Accessed: Jan. 20, 2020. doi: 10.1007/s11947-014-1285-y.

MENDOZA, F. A. et al. Prediction of canned black bean texture (Phaseolus vulgaris L.) from intact dry seeds using visible/near infrared spectroscopy and hyperspectral imaging data. Journal of the Science of Food and Agriculture, 2017, v.98, p.283-290. Available from: <https://onlinelibrary.wiley.com/doi/full/10.1002/ jsfa.8469>. Accessed: Jan. 20, 2020. doi: 10.1002/jsfa.8469.

MENDOZA, F.; et al. Calibrated color measurements of agricultural foods using image analysis. Postharvest Biology and Technology, 2006, v.41, p.285-295. Available from: <https://www. sciencedirect.com/science/article/abs/pii/S0925521406001116>. Accessed: Jan. 20, 2020. doi: 10.1016/j.postharvbio.2006.04.004.

MERWE, D. et al. Comparison of the canning quality of small white beans (Phaseolus vulgaris L.) canned in tomato sauce by a small-scale and an industrial method. Journal of the Science of Food and Agriculture, 2006a. v.86, n.7, p.1046-1056. Available from: <https://onlinelibrary.wiley.com/doi/abs/10.1002/ jsfa.2453>. Accessed: Jan. 20, 2020. doi: 10.1002/jsfa.2453.

MERWE, D. V. D.; OSTHOFF, G.; BLACKRIUS, A. J. Evaluation and standardization of small-scale canning methods for small white beans (Phaseolus vulgaris L.) canned in tomato sauce. Journal of the Science of Food and Agricultural, 2006b, v.86, p.1115-1124. Available from: <https://doi.org/10.1002/jsfa.2476>. Accessed: Jan. 20, 2020. doi: 10.1002/jsfa.2476.

MERWE, M. VAN DER; OSTHOFF, G.; PRETORIUS, A. J. A canning quality model for small white bean lines selected for breeding (Phaseolus vulgaris L.). South African Journal of Plant and Soil, 2008. v.25, n.1, p.22-31. January, 20, 2020. Available from: <https://www.tandfonline.com/doi/pdf/10.10 80/02571862.2008.10639891>. Accessed: Jan. 20, 2020. doi: $10.1080 / 02571862.2008 .10639891$.

OSORIO-DÍAZ, P. et al. In vitro digestibility and resistant starch content of some industrialized commercial beans (Phaseolus vulgaris L.). Food Chemistry, 2002. v.78, n.3, p.333-337. Available from: <https://www.sciencedirect.com/science/article/ 
pii/S0308814602001176>. Accessed: Jan. 20, 2020. doi: 10.1016/ S0308-8146(02)00117-6.

PEDROSA, M. M. et al. Effects of industrial canning on the proximate composition, bioactive compounds contents and nutritional profile of two Spanish common dry beans (Phaseolus vulgaris L.). Food Chemistry, 2015. v.166, p.68-75. Avaliable from: $\quad<$ http://dx.doi.org/10.1016/j.foodchem.2014.05.158>. Accessed: Jan. 20, 2020. doi: 10.1016/j.foodchem.2014.05.158.

POSA-MACALINCAG, M. C. T. et al. Quantitative trait loci (QTL) analysis of canning quality traits in kidney bean (Phaseolus vulgaris L.). Journal of the American Society for Horticultural Science, 2002. v.127, n.4, p.608-615. Available from: <https:// journals.ashs.org/jashs/view/journals/jashs/127/4/article-p608. xml>. Accessed: Jan. 20, 2020. doi: 10.21273/JASHS.127.4.608.

SCHOENINGER, V. et al. Industrial processing of canned beans. Ciencia Rural, 2017. v.47, n.5, p.1-9. Available from: $<$ http://www.scielo.br/scielo.php?script=sci_arttext\&pid $=$ S0103-84782017000500780 $>$. Accessed: Jan. 20, 2020. doi: $10.1590 / 0103-8478 \mathrm{cr} 20160672$.

SIDDIQ, M.; UEBERSAX, M. A. Dry beans and pulses production and consumption - an overview. In: SIDDIQ, M.; UEBERSAX, M.A. Dry beans and pulses: production, processing and nutrition. (2013). Ames: John Wiley \& Sons, 3-22.

SIQUEIRA, B. S. et al. Influence of Storage on Darkening and Hardening of Slow- and Regular-Darkening Carioca Bean (Phaseolus vulgaris L.) Genotypes. Journal of Agricultural Studies, 2014. v.2, n.2, p.87. Available from: <http://www. macrothink.org/journal/index.php/jas/article/view/5859>. Accessed: Jan. 20, 2020. doi: 10.5296/jas.v2i2.5859.
SLUPSKI, J. Effect of cooking and sterilization on the composition of amino acids in immature seeds of flageolet bean (Phaseolus vulgaris L.) cultivars. Food Chemistry, 2010, v.121, p.1171-1176, 2010. Available from: <https://www.sciencedirect.com/science/ article/pii/S0308814610001469>. Accessed: Jan. 20, 2020. doi: 10.1016/j.foodchem.2010.01.066.

WANDER, A. E.; BASSINElO, P. Z.; RICARDO, T. R. Perfil dos consumidores de arroz e feijão na região metropolitana de Goiânia. Comunicado Técnico, 127, Santo Antônio de Goiás: Embrapa Arroz e Feijão. (2006). Available from: < https://www. embrapa.br/busca-de-publicacoes/-/publicacao/214889/perfildos-consumidores-de-arroz-e-feijao-na-regiao-metropolitana-degoiania>. Accessed: Jan. 20, 2020.

WALTERS, K. J. et al. Navy bean canning quality: correlations, heritability estimates, and randomly amplified polymorphic DNA markers associated with component traits. Journal of the American Society for Horticultural Science, 1997, v.122, p.338-343. Available from: <https://journals.ashs.org/jashs/view/ journals/jashs/122/3/article-p338.xml>. Accessed: Jan. 20, 2020. doi: 10.21273/JASHS.122.3.338.

WHITE, B.; HOWARD, L. R. Canned whole dry beans and bean products. In: Siddiq, M.; Uebersax, M. A. Dry beans and pulses: production, processing and nutrition. (2013). Ames: John Wiley \& Sons, 155 - 183 .

WRIGHT, E. M.; KELLY, J. D. Mapping QTL for seed yield and canning quality following processing of black bean (Phaseolus vulgaris L.). Euphytica, 2011. v.179, n.3, p.471-484. Available from: <https://link.springer.com/ article/10.1007/s10681-011-0369-2>. Accessed: Jan. 20, 2020. doi: 10.1007/s10681-011-0369-2. 